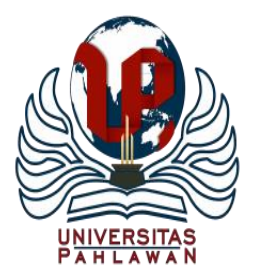

Jurnal Basicedu Volume 5 Nomor 1 Tahun 2021 Halaman 206-217

JURNAL BASICEDU

Research \& Learning in Elementary Education

https://jbasic.org/index.php/basicedu

\title{
Pengembangan Bahan Ajar Digital Matematika SD Menggunakan Whiteboard Animation untuk Mahasiswa PGSD STKIP PGRI Lubuklinggau
}

\author{
Akmal Rijal' ${ }^{1}$ Azimi $^{2}$ \\ PGSD STKIP PGRI Lubuklinggau ${ }^{1,2}$ \\ E-mail : $\underline{\text { kmalrijal3@gmail.com }}^{1}, \underline{\text { azimi.fkip@gmail.com }}^{2}$
}

\begin{abstract}
Abstrak
Permasalahan yang muncul dalam dunia pendidikan saat ini antara lain meliputi masih rendahnya kompetensi guru dan dosen dalam era pendidikan 4.0 yaitu mengembangkan bahan ajar atau materi digital, oleh sebab itu maka seorang guru atau dosen harus memiliki berbagai keterampilan di antaranya yaitu keterampilan dalam mengembangkan bahan ajar digital yang tepat. Penelitian ini bertujuan untuk mengembangkan bahan ajar digital Matematika SD menggunakan whiteboard animation untuk mahasiswa PGSD STKIP PGRI Lubuklinggau yang teruji valid dan praktis. Penelitian ini menggunakan pendekatan penelitian pengembangan dari Plomp yang terdiri dari tiga tahapan yaitu: preliminary research, prototyping phase, dan assesment phase. Subjek penelitian ini adalah mahasiswa PGSD semester V di STKIP PGRI Lubuklinggau. Teknik pengumpulan data menggunakan angket, observasi dan wawancara. Teknik analisis data yang digunakan adalah analisis deskriptif yang mendeskripsikan validitas dan praktikalitas. Hasil penelitian menunjukkan bahwa bahan ajar yang dikembangkan memenuhi kriteria valid dari segi isi dan konstruk dengan nilai rata-rata 95\%. Bahan ajar sudah praktis baik dari segi keterlaksanaan, kemudahan, dan waktu yang diperlukan dengan rata-rata nilai 92,5\%. Berdasarkan hasil tersebut dapat disimpulkan bahwa bahan ajar yang dikembangkan dapat dinyatakan valid dan praktis.
\end{abstract}

Kata kunci: bahan ajar, whiteboard animation, matematika SD, PGSD, STKIP PGRI Lubuklinggau.

\section{Abstract}

The problems that arise in the world of education today include the low competence of teachers and lecturers in the era of education 4.0, namely developing teaching materials or digital material, therefore a teacher or lecturer must have various skills including skills in developing digital teaching materials right. This study aims to develop digital elementary mathematics teaching materials using whiteboard animation for primary teacher education STKIP PGRI Lubuklinggau students which has been tested valid and practical. This study uses a research development approach from Plomp which consists of three stages, namely: preliminary research, prototyping phase, and assessment phase. The subjects of this study were fifth semester primary teacher education students at STKIP PGRI Lubuklinggau. Data collection techniques using questionnaires, observation and interviews. The data analysis technique used is descriptive analysis which describes the validity and practicality. The results showed that the teaching materials developedment the valid criteria in terms of content and construct with an average value of $95 \%$. Teaching materials are practical both in terms of implementation, convenience, and time required with an average value of $92.5 \%$. Based on these results it can be concluded that the teaching materials developed can be declared valid and practical.

Keywords: teaching materials, whiteboard animation, elementary school math, primary teacher education, STKIP PGRI Lubuklinggau.

Copyright (c) 2021 Akmal Rijal, Azimi

Corresponding author :

Address : STKIP PGRI Lubuklinggau

Email : akmalrijal3@gmail.com

ISSN 2580-3735 (Media Cetak)

Phone : 085368195220

ISSN 2580-1147 (Media Online)

DOI: https://doi.org/10.31004/basicedu.v5i1.640 
207 Pengembangan Bahan Ajar Digital Matematika SD Menggunakan Whiteboard Animation Untuk Mahasiswa PGSD STKIP PGRI Lubuklinggau- Akmal Rijal, Azimi

DOI: https://doi.org/10.31004/basicedu.v5i1.640

\section{PENDAHULUAN}

Perkembangan teknologi yang semakin hari semakin cepat memberikan pengaruh yang besar dalam bidang pendidikan. Menyiapkan lulusan yang berkualitas dan mampu bersaing secara global, dan menguasai perkembangan teknologi merupakan hal yang penting untuk semua orang dan penting bagi masa depan suatu negara (Barry, 2016). Pendidikan harus menyiapkan lulusan yang berkualitas dan mampu bersaing secara global, serta menguasai perkembangan teknologi. (Kementerian riset teknologi dan pendidikan tinggi, 2018) menyatakan bahwa era revolusi industri 4.0 akan mendisrupsi berbagai kegiatan atau aktivitas manusia, termasuk di dalamnya bidang iptek serta pendidikan tinggi. Permasalahan yang muncul dalam dunia pendidikan saat ini antara lain meliputi masih rendahnya kompetensi guru dan dosen dalam era pendidikan 4.0 yaitu mengembangkan bahan ajar atau materi digital yang tepat.

Bahan ajar menurut (Kementerian Pendidikan dan Kebudayaan, 2016) adalah segala bentuk bahan yang digunakan untuk membantu guru dalam melaksanakan proses pembelajaran. Contoh dari bahan ajar yaitu seperti buku, modul, dan lembar kerja siswa yang masih dalam bentuk cetak (printed). Namun dengan adanya perkembangan teknologi saat ini, bahan ajar tidak berbentuk cetak lagi melainkan dalam bentuk digital multimedia. Teknologi digital ini erat kaitannya dengan penggunaan komputer, laptop, smartphone, notebook, internet dan alat-alat digital lainnya. Menurut (Weaver, Barbara E. \& Nilson, 2005), perangkat digital seperti laptop/notebook mempunyai berbagai fungsi yang sangat penting bagi pembelajaran di kelas. Pernyataan tersebut membuat pendidik sebaiknya berpikir terbuka (open minded) pada perkembangan teknologi masa kini, mengingat sebagian besar mahasiswa merupakan pengguna aplikasi teknologi terutama komputer. Pengembangan bahan ajar digital harus disesuaikan dengan karakteristik mahasiswa dan perkembangan jaman yaitu salah satunya adalah bahan ajar whiteboard animation.

Whiteboard animation atau biasa disebut animasi drawing merupakan konten video animasi dengan menyajikan presentasi bahan ajar/materi berbasis animasi (sketch drawing) yang menarik dan mudah dipelajari. Platform yang digunakan dalam penelitian ini adalah sparkol videoscribe. Sparkol videoscribe adalah aplikasi online untuk membuat desain presentasi animasi berlatar putih sebagai media presentasi yang unik dan kreatif sehingga bermanfaat untuk guru dan dosen dalam menyajikan materi pembelajaran. Dalam belajar Matematika, seseorang dituntut untuk menyiapkan mentalnya pada saat penerimaan informasi baru yang ditandai dengan tindakan nyata melalui pemecahan masalah Matematika melalui pemilihan bahan ajar yang sesuai sehingga hasil belajar siswa semakin baik.

Mengatasi permasalahan diatas, maka diperlukan pengembangan bahan ajar atau materi digital yang tepat digunakan dalam pembelajaran daring pada menggunakan whiteboard animation. Pengembangan bahan ajar digital bertujuan agar dapat mengarahkan mahasiswa untuk mampu memecahkan masalah terbuka, berorientasi pada karakteristik siswa, membuat mahasiswa dan guru 
208 Pengembangan Bahan Ajar Digital Matematika SD Menggunakan Whiteboard Animation Untuk Mahasiswa PGSD STKIP PGRI Lubuklinggau- Akmal Rijal, Azimi

DOI: https://doi.org/10.31004/basicedu.v5i1.640

menjadi melek teknologi, mempercepat era 5.0 dan meningkatkan kemampuan di bidang ilmu teknologi. Bahan ajar digital matematika SD menggunakan whiteboard animation sangat penting karena dapat memberikan kebermanfaatan dan merupakan salah satu inovasi yang bagus dan perlu untuk ditingkatkan dengan harapan sistem informasi teknologi dapat dikuasai dan menjadi lebih pintar lagi dalam menggunakan teknologi yang ada.

Berdasarkan latar belakang masalah di atas maka peneliti tertarik untuk melakukan penelitian pengembangan bahan ajar digital matematika SD menggunakan whiteboard animation untuk mahasiswa PGSD STKIP PGRI Lubuklinggau. Adapun tujuan khusus melalui skema penelitian dosen pemula ini diharapkan dapat mengembangkan bahan ajar digital matematika SD menggunakan whiteboard animation untuk mahasiswa PGSD STKIP PGRI Lubuklinggau yang teruji valid dan praktis, membina atau meningkatkan kemampuan meneliti, menjadi sarana latihan untuk mempublikasikan hasil penelitiannya dalam jurnal ilmiah nasional terakreditasi dan menginisiasi penyusunan peta jalan penelitian.

\section{METODE}

Penelitian ini merupakan penelitian dan pengembangan (research and development). Pada penelitian ini akan dirancang produk bahan ajar digital Matematika sekolah dasar whiteboard animation. Penelitian dan pengembangan menggunakan model pengembangan Plomp (research and development) (Plomp, 2013), adapun prosedur dalam penelitian ini adalah, (1) preliminary research, (2) prototyping phase, and (3) assesment phase. Subjek pada penelitian adalah mahasiswa Pendidikan Guru Sekolah Dasar semester V di STKIP PGRI Lubuklinggau. Penelitian ini dilaksanakan pada bulan Juli sampai bulan Agustus 2020 di STKIP PGRI Lubuklinggau. Instrumen dan metode pengumpulan data dalam penelitian ini adalah dengan wawancara, angket dan observasi dengan lembar angket validasi produk, angket kepraktisan dan lembar wawancara kepraktisan. Teknik analisis data yang digunakan adalah analisis deskriptif yang mendeskripsikan dengan skala likert berdasarkan lembar validasi dan praktikalitas sesuai kategori, sedangkan data hasil wawancara dan observasi dianalisis secara kualitatif.

\section{HASIL DAN PEMBAHASAN}

Setelah melakukan analisis pendahuluan, merancang prototipe, menvalidasi bahan ajar digital matematika SD menggunakan whiteboard animation untuk mahasiswa PGSD STKIP PGRI Lubuklinggau dan melaksanakan uji praktikalitas, maka hasil penelitian dan pembahasan disajikan sebagai berikut.

\section{Hasil}

Hasil analisis Rencana Pembelajaran Semester (RPS) dijabarkan menjadi deskripsi mata kuliah yaitu untuk menguasai berbagai kemampuan dan keterampilan mengajarkan materi-materi pelajaran Matematika sekolah dasar, yang berhubungan dengan bilangan yaitu konsep 
209 Pengembangan Bahan Ajar Digital Matematika SD Menggunakan Whiteboard Animation Untuk Mahasiswa PGSD STKIP PGRI Lubuklinggau- Akmal Rijal, Azimi

DOI: https://doi.org/10.31004/basicedu.v5i1.640

bilangan dan macam-macam bilangan. Isi kurikulum tersebut dinilai sudah baik untuk mencapai tujuan pembelajaran sehingga tidak dilakukan perubahan urutan materi karena telah menjabarkan materi yang sesuai dalam mengembangkan isi bahan ajar digital Matematika SD menggunakan whiteboard animation. Hasil analisis kurikulum inilah yang dijadikan sebagai pertimbangan untuk membuat bahan ajar digital Matematika SD menggunakan whiteboard animation untuk mahasiswa PGSD STKIP PGRI Lubuklinggau.

Analisis konsep merupakan identifikasi materi-materi pokok yang akan dibahas pada pembelajaran. Materi disusun secara sistematis dengan menggunakan peta konsep sehingga materi yang akan dibahas dapat dilihat dengan spesifik. Materi bilangan dan operasi hitung terdapat pada pertemuan 1 yaitu menguasai materi-materi, mengajarkan materi, membuat media pembelajaran yang berkaitan dengan bilangan dan menyelesaikan masalah yang berkaitan dengan bilangan, materi sudah terurut dengan baik.

Hasil analisis karakteristik mahasiswa semester V program studi PGSD STKIP PGRI Lubuklinggau adalah memiliki rasa ingin tahu yang cukup tinggi, senang dengan sesuatu hal yang baru dan menarik dan menyukai TIK, atas dasar karakteristik mahasiswa yang demikian, maka dilakukan penelitian yang menghadirkan sarana belajar yang berbeda dari yang digunakan sebelumnya, yaitu pembelajaran daring dengan internet, serta mengembangkan rasa ingin tahu kearah yang positif, yang erat kaitannya dengan perkembangan proses berpikir mahasiswa khususnya di masa pendemi Covid-19 saat ini.

Analisis tempat penelitian dilakukan dengan cara mengamati proses perkuliahan selama ini yang dilaksanakan di program studi PGSD STKIP PGRI Lubuklinggau. Hasil analisis tempat penelitian yang dilaksanakan di lapangan bahwa sudah adanya hotspot area di perguruan tinggi memungkinkan sekali untuk pengembangan proses belajar mengajar menggunakan pemanfaatan internet khususnya pada saat pandemi Covid-19 saat ini, baik di kampus maupun saat mahasiswa berada di rumah yang mengharuskan proses perkuliahan daring. Selanjutnya pemanfaatan internet sebagai sumber belajar masih belum maksimal, baik oleh dosen maupun mahasiswa.

Kegiatan selanjutnya yang dilakukan setelah tahap pendahuluan adalah merancang dan mengembangkan prototipe bahan ajar digital matematika SD menggunakan whiteboard animation. Hasil rancangan prototipe awal ini diberi nama prototipe 1. Berikut ini akan diuraikan karakteristik bahan ajar digital Matematika SD menggunakan whiteboard animation yang telah dirancang. Karakteristik bahan ajar digital Matematika SD menggunakan whiteboard animation yang dikembangkan yaitu agar dapat digunakan untuk mengarahkan mahasiswa untuk mampu memecahkan masalah terbuka, berorientasi pada karakteristik siswa, membuat mahasiswa menjadi melek teknologi, mempercepat era 5.0 dan meningkatkan kemampuan di bidang ilmu pengetahuan dan teknologi. Bahan ajar digital matematika SD menggunakan whiteboard animation yang dikembangkan mengacu pada 
210 Pengembangan Bahan Ajar Digital Matematika SD Menggunakan Whiteboard Animation Untuk Mahasiswa PGSD STKIP PGRI Lubuklinggau- Akmal Rijal, Azimi

DOI: https://doi.org/10.31004/basicedu.v5i1.640

indikator-indikator yang telah dirumuskan sebelumnya. Penyajian bahan ajar digital Matematika SD menggunakan whiteboard animation diproses dengan menggunakan platform videoscribe dari sparkol yang dapat di download langsung di situsnya www.videoscribe.co dengan materi konsep bilangan dan macam-macam bilangan.

Setelah mengunduh videoscribe dilakukan penginstallan program dan mendaftar akun terlebih dahulu, adapun versi yang digunakan dalam penelitian ini yaitu sparkol videoscribe 3.2.1. Langkah selanjutnya yaitu membuat storyline. Storyline merupakan naskah dalam bentuk teks yang merupakan alur cerita yang disusun sebagai urutan bagian-bagian dalam keseluruhan topik/gagasan dengan tujuan agar memiliki panduan yang jelas sehingga animasi menjadi lebih tersusun rapi. Topik yang diangkat dalam pengembangan ini yaitu konsep bilangan yang dilengkapi dengan sinopsis dengan memuat kolom slide, alur cerita, gambar, musik dan perkiraan durasi.

Setelah membuat storyline, selanjutnya adalah membuka aplikasi videoscribe dengan login menggunakan e-mail dan password yang telah dibuat sebelumnya. Setelah login akan tampil halaman awal dan pilih create new scribe. Dalam aplikasi ini terdapat berbagai fitur untuk menambahkan elemen-elemen dalam memproduksi animasi seperti add image, add text, add voiceover, dan add soundtrack. Proyek yang dibuat sesuai dengan storyline yang telah kita buat sebelumnya yaitu materi konsep bilangan yang dilengkapi dengan sinopsis/ deskripsi topik/ materi dengan menambahkan judul, tulisan, fitur animasi, suara, dan musik. Proyek yang telah kita buat dapat disimpan dalam save locally, save online/cloud, save snapshot, dan export scribe dalam komputer dengan ekstensi scribe, avi, mp4, $J P G, P N G$, dan $P P T$. Aplikasi ini juga terdapat fitur untuk publikasi bahan ajar untuk siswa ke media sosial facebook dan youtube. Spesifikasi dari bahan ajar digital Matematika SD menggunakan whiteboard animation terdiri dari opening title, materi bilangan, soal latihan dan closing.

Bahan ajar yang telah dirancang dievaluasi dengan instrumen self evaluation. Setelah dilakukan evaluasi maka bahan ajar direvisi. Revisi dilakukan pada bahan ajar yaitu kesalahankesalahan dalam penulisan dan penempatan tulisan pada bahan ajar. Bahan ajar direvisi kembali sesuai dengan temuan. Bahan ajar mata kuliah pembelajaran Matematika SD selanjutnya didiskusikan dengan rekan penelitian. Kemudian bahan ajar divalidasi oleh validator. Validator merupakan rekan sejawat, yang menjadi validator berasal dari dosen dengan 3 bidang keahlian yaitu materi, media, dan bahasa. Persentase rata-rata skor penilaian bahan ajar digital Matematika SD menggunakan whiteboard animation yang diperoleh dari 3 kriteria yaitu (1) aspek materi dengan kategori sangat valid, (2) aspek bahasa dengan kategori sangat valid, dan (3) aspek media dengan kategori sangat valid. Ketiga kriteria data yang disajikan dapat disimpulkan bahwa rata-rata validasi bahan ajar digital Matematika SD menggunakan whiteboard animation secara 
211 Pengembangan Bahan Ajar Digital Matematika SD Menggunakan Whiteboard Animation Untuk Mahasiswa PGSD STKIP PGRI Lubuklinggau- Akmal Rijal, Azimi

DOI: https://doi.org/10.31004/basicedu.v5i1.640

keseluruhan adalah 95\% dengan kategori sangat valid yang dapat dilihat pada tabel 1 berikut.

Tabel 1. Hasil Validasi Bahan Ajar Digital Matematika SD Menggunakan Whiteboard Animation

\begin{tabular}{|c|lr|c|c|}
\hline No. & \multicolumn{1}{|c|}{ Validator } & $\begin{array}{c}\text { Rata-rata } \\
(\mathbf{\%})\end{array}$ & Kategori \\
\hline 1. & $\begin{array}{l}\text { Validator } \\
\text { (Materi) }\end{array}$ & 96 & $\begin{array}{c}\text { Sangat } \\
\text { Valid }\end{array}$ \\
\hline 2. & $\begin{array}{l}\text { Validator II } \\
\text { (Bahasa) }\end{array}$ & 94 & $\begin{array}{c}\text { Sangat } \\
\text { Valid }\end{array}$ \\
\hline 3. & $\begin{array}{l}\text { Validator III } \\
\text { (Media) }\end{array}$ & 94 & $\begin{array}{c}\text { Sangat } \\
\text { Valid }\end{array}$ \\
\hline & Rata-rata & $\mathbf{9 5}$ & $\begin{array}{c}\text { Sangat } \\
\text { Valid }\end{array}$ \\
\hline
\end{tabular}

Praktikalitas bahan ajar digital Matematika SD menggunakan whiteboard animation pada tahap one to one evaluation adalah $99 \%$ dengan kategori sangat praktis. Hasil wawancara mahasiswa menyatakan tertarik belajar dengan bahan ajar digital Matematika SD menggunakan whiteboard animation yang telah dirancang karena kegiatannya menarik dan mudah digunakan. Mahasiswa juga menyatakan memahami materi yang ada dalam bahan ajar dan tidak terlalu banyak membutuhkan arahan untuk menyelesaikan setiap kegiatan.

Rata-rata hasil praktikalitas bahan ajar digital Matematika SD menggunakan whiteboard animation pada tahap small group adalah $96 \%$ dengan kategori sangat praktis. Hasil wawancara mahasiswa menyatakan tertarik belajar dengan bahan ajar yang telah dirancang karena kegiatannya menarik, praktis, mudah dan jelas. Mahasiswa juga menyatakan memahami materi yang ada dalam bahan ajar dan tidak terlalu banyak membutuhkan arahan untuk menyelesaikan setiap kegiatan.

Adapun hasil tingkat kepraktisan bahan ajar digital Matematika SD menggunakan whiteboard animation menurut respon mahasiswa dari angket praktikalitas respon mahasiswa pada tahap field test adalah 92,5\%. Jadi, dapat disimpulkan bahwa bahan ajar digital Matematika SD menggunakan whiteboard animation dinyatakan sangat praktis. Hasil keseluruhan praktikalitas bahan ajar dapat dilihat pada tabel 2 berikut.

Tabel 2. Hasil Praktikalitas Bahan Ajar Digital Matematika SD Menggunakan Whiteboard Animation

\begin{tabular}{|c|l|c|c|}
\hline No. & \multicolumn{1}{|c|}{ Tahap } & $\begin{array}{c}\text { Rata-rata } \\
(\mathbf{\%})\end{array}$ & Kategori \\
\hline 1. & $\begin{array}{l}\text { One to One } \\
\text { Evaluation }\end{array}$ & 99 & $\begin{array}{l}\text { Sangat } \\
\text { Praktis }\end{array}$ \\
\hline 2. & Small Group & 96 & $\begin{array}{l}\text { Sangat } \\
\text { Praktis }\end{array}$ \\
\hline 3. & Field Test & 92.5 & $\begin{array}{l}\text { Sangat } \\
\text { Praktis }\end{array}$ \\
\hline & Rata-rata & $\mathbf{9 5 . 8 3}$ & $\begin{array}{l}\text { Sangat } \\
\text { Praktis }\end{array}$ \\
\hline
\end{tabular}

Berdasarkan tabel 2 dapat disimpulkan bahwa bahan ajar digital Matematika SD menggunakan whiteboard animation dinyatakan sangat praktis. Secara keseluruhan berdasarkan hasil observasi pembelajaran pada aktivitas perkuliahan daring dengan bahan ajar ini berjalan dengan lancar, tidak ada kendala berarti yang dihadapi oleh dosen dan mahasiswa. Semua mahasiswa terlihat begitu antusias dan lebih banyak aktif dalam belajar. Hasil wawancara dengan mahasiswa juga ditemukan bahwa rata-rata mahasiswa senang belajar menggunakan bahan ajar digital Matematika SD menggunakan 
212 Pengembangan Bahan Ajar Digital Matematika SD Menggunakan Whiteboard Animation Untuk Mahasiswa PGSD STKIP PGRI Lubuklinggau- Akmal Rijal, Azimi

DOI: https://doi.org/10.31004/basicedu.v5i1.640

whiteboard animation karena tampilan yang menarik dan aktivitas perkuliahan yang menyenangkan. Mahasiswa juga merasa tidak membutuhkan banyak arahan dari dosen selama menyelesaikan aktivitas dalam bahan ajar digital Matematika SD menggunakan whiteboard animation karena petunjuk dan langkah kerja yang diberikan sudah cukup jelas. Selain itu, mahasiswa mengakui ada manfaat yang dirasakannya setelah belajar dengan menggunakan bahan ajar digital Matematika SD menggunakan whiteboard animation, mahasiswa merasa lebih memahami materi dan dapat mencoba menerapkan konsep yang sesuai dengan materi yang telah dipelajari secara mandiri.

\section{Pembahasan}

Paparan pembahasan mengenai hasil penelitian pengembangan yang telah dilakukan akan diuraikan lebih lanjut terutama yang berkaitan dengan validitas dan praktikalitas produk yang dikembangkan. Untuk lebih jelasnya pembahasan tersebut diuraikan sebagai berikut.

\section{Validitas}

Validitas diperlukan untuk menguji suatu penelitian. Kata "valid" sering diartikan dengan shahih atau absah. Validitas berasal dari kata validity yang mempunyai arti sejauh mana ketepatan dan kecermatan suatu alat ukur dalam melakukan fungsi ukurnya. Selain itu, validitas adalah suatu ukuran yang menunjukkan tingkat keandalan dan kesahihan suatu alat ukur (Suharsimi, 2012). Dengan demikian, validitas adalah suatu ukuran yang menunjukkan tingkat kesahihan suatu yang diukur dengan tepat dan cermat. Valid artinya penilaian sudah memberikan informasi yang akurat tentang media yang dikembangkan. Bahan ajar digital Matematika SD menggunakan whiteboard animation yang dikembangkan dinyatakan valid apabila telah memenuhi syarat-syarat yang telah ditetapkan baik secara isi maupun konstruk, sesuai dengan pendapat (Nieveen, 2007), karakteristik dari produk yang dikatakan valid apabila produk tersebut komponen-komponennya didasarkan pada prinsip pengetahuan, hal inilah yang disebut dengan validitas isi. Selanjutnya, komponenkomponen tersebut juga harus terkait secara konsisten satu sama lain atau disebut juga dengan validitas konstruk sejalan dengan pendapat lihat (Herawani, 2019). Pada penelitian ini validasi dirinci lagi menjadi validasi produk yang dilakukan terhadap materi, bahasa dan media.

Validitas bahan ajar digital Matematika SD menggunakan whiteboard animation melibatkan tiga orang validator, sesuai dengan pendapat (Sugiyono, 2011) bahwa validasi produk dapat dilakukan oleh beberapa pakar atau tenaga ahli yang sudah berpengalaman untuk menilai produk baru yang dirancang, sehingga selanjutnya dapat diketahui kelemahan dan keunggulannya. Hasil validasi dari ahli tersebut dikumpulkan kemudian dianalisis untuk dicari rata-rata dari masingmasing indikator dan masing-masing aspek.

Dari segi aspek materi, bahan ajar digital Matematika SD menggunakan whiteboard animation yang dikembangkan dinyatakan valid oleh validator dengan persentase nilai adalah $96 \%$ termasuk pada kategori sangat valid. Materi dalam 
213 Pengembangan Bahan Ajar Digital Matematika SD Menggunakan Whiteboard Animation Untuk Mahasiswa PGSD STKIP PGRI Lubuklinggau- Akmal Rijal, Azimi

DOI: https://doi.org/10.31004/basicedu.v5i1.640

bahan ajar digital Matematika SD menggunakan whiteboard animation yang dikembangkan sudah sesuai dengan RPS, sudah disajikan sesuai dengan kebutuhan mahasiswa, disajikan sesuai dengan kebutuhan pembelajaran, substansi materi yang disajikan jelas.

Dari segi aspek bahasa, bahan ajar digital Matematika SD menggunakan whiteboard animation yang dikembangkan dinyatakan valid oleh validator dengan persentase nilai rata-rata adalah 94\% termasuk pada kategori sangat valid. Bahasa dalam bahan ajar digital Matematika SD menggunakan whiteboard animation yang dikembangkan sudah menggunakan bahasa sesuai dengan Ejaan Yang Disempurnakan (EYD) mahasiswa, bahasa juga disajikan juga komunikatif dan penggunaan bahasa juga telah menggunakan struktur kalimat yang sederhana sehingga dapat membantu menambah wawasan mahasiswa dan setiap kegiatan yang disajikan telah mengacu pada tahapan penggunaan.

Dari segi aspek media, bahan ajar digital Matematika SD menggunakan whiteboard animation yang dikembangkan telah telah dinyatakan valid dengan persentase nilai rata-rata adalah 94\% termasuk pada kategori sangat valid. Bahan ajar digital Matematika SD menggunakan whiteboard animation dinilai sudah memenuhi kesesuaian media terhadap tujuan pembelajaran, format tampilan (layout) yang menarik, mengandung informasi yang berkualitas untuk memberikan pemahaman kepada mahasiswa, menyajikan gambaran kegiatan yang dilakukan dengan mudah dipahami, penggunaan huruf pada teks baik ukuran maupun warna dan mudah digunakan.

Hal ini sesuai dengan hasil penelitian yang telah dilakukan oleh (Suherman et al., 2019) dengan judul "Development of traditional children play based instructional model to optimize development of kindergarteners' fundamental motor skill'. Penelitian tersebut mengembangkan permainan tradisional anak usia dini untuk mengembangkan keterampilan motorik dasar karena elemen gerakan itu sesuai dengan kebutuhan untuk berkembang keterampilan motorik dasar anak-anak, dan mempertimbangkan persyaratan untuk anak taman kanak-kanak, karakteristik pembelajaran, dan kebutuhan ciri-ciri keterampilan motorik fundamental itu akan dikembangkan. Dengan hasil validasi menunjukkan bahwa instruksional model memiliki komponen berikut; (1) konsep landasan teori, (2) belajar-mengajar tahapan, (3) sistem sosial, (4) prinsip reaksi, (5) sistem pendukung, dan (6) dampak model.

Berdasarkan analisis kevalidan bahan ajar digital Matematika SD menggunakan whiteboard animation oleh validator dapat disimpulkan secara keseluruhan bahan ajar digital Matematika SD menggunakan whiteboard animation yang dikembangkan sudah termasuk kategori sangat valid dengan persentase nilai rata-rata keseluruhan untuk RPP 95\%. Penilaian yang valid terhadap bahan ajar digital Matematika SD menggunakan whiteboard animation yang dikembangkan menandakan bahwa bahan ajar digital Matematika SD menggunakan whiteboard animation dapat digunakan sebagai model media pembelajaran 
214 Pengembangan Bahan Ajar Digital Matematika SD Menggunakan Whiteboard Animation Untuk Mahasiswa PGSD STKIP PGRI Lubuklinggau- Akmal Rijal, Azimi

DOI: https://doi.org/10.31004/basicedu.v5i1.640

digital bagi perkuliahan yang berpusat pada peserta didik dan mendukung pembelajaran jarak jauh, dalam jaringan maupun luar jaringan bagi dosen dan mahasiswa di PGSD STKIP PGRI Lubuklinggau.

\section{Praktikalitas}

Untuk mengatur tingkat kepraktisan yang berkaitan dengan pengembangan instrumen berupa materi pembelajaran, (Nieveen, 2007) berpendapat bahwa untuk mengukur kepraktisannya dengan melihat apakah pendidik dan pakar-pakar lainnya mempertimbangkan bahwa materi mudah dan dapat digunakan oleh pendidik dan peserta didik. Menurut (Sukardi, 2011) ada beberapa pertimbangan praktikalitas yang dapat dilihat dari aspek-aspek berikut, yaitu kemudahan penggunaan seperti mudah diatur, mudah disimpan, dan dapat digunakan sewaktu-waktu, waktu yang diperlukan dalam pelaksanaan sebaiknya singkat, cepat, dan tepat, daya tarik perangkat terhadap minat peserta didik, mudah diinterpretasikan oleh ahli maupun pendidik lain, dan memiliki ekuivalensi yang sama, sehingga bisa digunakan sebagai pengganti atau variabel.

Bahan ajar digital Matematika SD menggunakan whiteboard animation yang telah dinyatakan valid oleh validator selanjutnya diujicobakan untuk melihat praktikalitasnya. Kemudian menurut (Plomp, 2013) suatu produk dapat dikatakan praktis apabila dapat digunakan dengan mudah oleh dosen dan mahasiswa sesuai dengan tujuan pengembangan. Bahan ajar digital Matematika SD menggunakan whiteboard animation dikatakan praktis, jika mahasiswa dapat menggunakan bahan ajar digital Matematika SD menggunakan whiteboard animation tersebut tanpa banyak masalah.

Uji praktikalitas ini dilakukan untuk mengungkap bagaimana kemudahan penggunaan bahan ajar digital Matematika SD menggunakan whiteboard animation, kesesuaian waktu dengan banyak dan bentuk tugas, daya tarik/minat mahasiswa terhadap bahan ajar digital Matematika SD menggunakan whiteboard animation dan keterbacaan bahan ajar digital Matematika SD menggunakan whiteboard animation oleh mahasiswa. Uji praktikalitas dilakukan melalui beberapa kegiatan, yaitu one to one evaluation, small group dan field test. Produk diuji cobakan pada mahasiswa melalui uji one to one evaluation. Uji one to one evaluation dilakukan terhadap dua orang mahasiswa semester V PGSD STKIP PGRI Lubuklinggau dengan kemampuan akademik yang berbeda. Uji ini dilakukan sebanyak satu kali pertemuan dengan materi yang berbeda secara daring. Pada akhir pertemuan mahasiswa diminta untuk mengisi angket dan juga dilakukan wawancara. Berdasarkan analisis hasil uji praktikalitas dengan menggunakan angket pada tahap one to one evaluation diperoleh rata-rata 99\% dengan kategori sangat praktis.

Berdasarkan hasil wawancara yang dilakukan mahasiswa juga diperoleh kesimpulan bahwa bahan ajar digital Matematika SD menggunakan whiteboard animation yang dikembangkan sudah menarik karena dilengkapi dengan aktivitas-aktivitas yang menarik dan memotivasi belajar bagi mahasiswa. Tampilan bahan ajar digital Matematika SD menggunakan 
215 Pengembangan Bahan Ajar Digital Matematika SD Menggunakan Whiteboard Animation Untuk Mahasiswa PGSD STKIP PGRI Lubuklinggau- Akmal Rijal, Azimi

DOI: https://doi.org/10.31004/basicedu.v5i1.640

whiteboard animation juga sudah menarik, sehingga mahasiswa lebih bersemangat untuk mempelajari materi. Selain itu, mahasiswa juga menyatakan tidak terlalu banyak membutuhkan arahan selama menyelesaikan setiap aktivitas pada bahan ajar digital Matematika SD menggunakan whiteboard animation.

Setelah melalui uji one to one evaluation, uji praktikalitas dilanjutkan dengan uji coba small group. Uji praktikalitas small group dilakukan dengan memberikan bahan ajar digital Matematika SD menggunakan whiteboard animation pada empat orang mahasiswa semester V PGSD STKIP PGRI Lubuklinggau. Uji praktikalitas pada tahap ini dilakukan sebanyak satu kali pertemuan dan mahasiswa diminta mengisi angket dan dilakukan wawancara.

Hasil analisis angket praktikalitas mahasiswa diperoleh nilai rata-rata $96 \%$ dengan kategori sangat praktis. Hasil wawancara dengan mahasiswa juga menunjukkan bahwa mahasiswa menyatakan sangat menarik karena dilengkapi dengan aktivitas-aktivitas yang menarik dan memotivasi belajar bagi mahasiswa. Tampilan bahan ajar digital Matematika SD menggunakan whiteboard animation, sehingga mahasiswa lebih bersemangat untuk mempelajari materi. Selain itu, mahasiswa juga menyatakan tidak terlalu banyak membutuhkan arahan selama menyelesaikan setiap aktivitas bahan ajar digital Matematika SD menggunakan whiteboard animation.

Setelah uji coba small group, bahan ajar digital Matematika SD menggunakan whiteboard animation selanjutnya diujicobakan pada tahap ujicoba field test yang dilakukan sebanyak satu kali pertemuan pada mahasiswa semester V PGSD STKIP PGRI Lubuklinggau. Data praktikalitas diperoleh melalui angket praktikalitas respon mahasiswa dan wawancara. Uji lapangan dilakukan dengan meminta mahasiswa melaksanakan perkuliahan dengan menggunakan bahan ajar digital Matematika SD menggunakan whiteboard animation yang telah dirancang. Pelaksanaan penggunaan yang dilakukan diamati dan diakhir perkuliahan pertemuan mahasiswa diminta untuk mengisi angket dan pedoman wawancara. Rata-rata persentase hasil analisis angket kepraktisan dari sudut pandang mahasiswa adalah 92,5\% dengan kategori sangat praktis.

Hasil wawancara dengan mahasiswa juga tidak jauh berbeda dengan tahap one to one evaluation dan small group, mahasiswa menyatakan ketertarikannya menggunakan bahan ajar digital Matematika SD menggunakan whiteboard animation. Hasil wawancara juga terungkap bahwa mahasiswa menyukai bahan ajar digital Matematika SD menggunakan whiteboard animation, karena setiap tahapan aktivitas pada bahan ajar bahan ajar digital Matematika SD menggunakan whiteboard animation membantu meningkatkan motivasi dan aktivitas belajar mahasiswa dengan mengajak mahasiswa melakukan aktivitas perkuliahan secara mandiri dan bermacam sumber belajar dan latihan yang menarik.

Hal ini sesuai dengan hasil penelitian yang telah dilakukan oleh (Wijayanti et al., 2018) dengan judul "Media comic math berbasis whiteboard annimation dalam pelajaran Matematika". Penelitian tersebut menganalisis 
216 Pengembangan Bahan Ajar Digital Matematika SD Menggunakan Whiteboard Animation Untuk Mahasiswa PGSD STKIP PGRI Lubuklinggau- Akmal Rijal, Azimi

DOI: https://doi.org/10.31004/basicedu.v5i1.640

perancangan comic math berbasis whiteboard animation merupakan alat yang mempunyai fungsi menyampaikan materi pelajaran dengan menggabungkan cerita (materi pelajaran) dengan ilustrasi animasi yang bergerak. Penggunaan media comic math berbasis whiteboard animation dalam proses pembelajaran dapat mempermudah siswa dalam memahami materi yang disampaikan oleh guru. Berdasarkan hasil penelitian pengembangan media pembelajaran Matematika comic math berbasis whiteboard animation layak untuk digunakan dalam proses pembelajaran Matematika di sekolah, karena memliki karakteristik sesuai dengan tingkatan siswa dan mempunyai ketertarikan sehingga peserta didik lebih giat untuk belajar.

Dari hasil penelitian di atas dapat dilihat bahwa peserta didik menunjukkan motivasi dan kenyamanan yang bagus setelah belajar dengan bahan ajar digital Matematika SD menggunakan whiteboard animation. Penggunaan bahan ajar digital Matematika SD menggunakan whiteboard animation juga layak digunakan karena memliki karakteristik sesuai dengan tingkatan mahasiswa dan mempunyai ketertarikan sehingga mahasiswa lebih giat untuk belajar dalam proses perkuliahan hali ini sejalan dengan pendapat (Desvianti ${ }^{1}$, Desyandri $^{2}$, Darmansyah ${ }^{3}, 2020$ ) hasil belajar yang diperoleh siswa pada pelaksanaan pembelajaran ini tidak hanya merujuk kepada peningkatan kemampuan pada hasil saja, tetapi juga pada proses pemerolehan pengetahuan yang diperoleh setelah ia menerima pengalaman belajar. Secara umum dapat disimpulkan dari hasil analisis angket respon mahasiswa dan wawancara yang dilakukan bahwa bahan ajar digital Matematika SD menggunakan whiteboard animation yang dikembangkan sudah dikategorikan praktis untuk digunakan oleh mahasiswa.

\section{SIMPULAN}

Penelitian ini merupakan penelitian pengembangan yang menghasilkan bahan ajar digital Matematika SD menggunakan whiteboard animation. Berdasarkan hasil pengembangan dan uji coba bahan ajar digital Matematika SD menggunakan whiteboard animation diperoleh kesimpulan sebagai berikut.

1. Telah dihasilkan bahan ajar digital Matematika SD menggunakan whiteboard animation dengan kategori rata-rata hasil validasi keseluruhan $95 \%$ dengan kategori sangat valid, berdasarkan hasil validasi perangkat pembelajaran oleh validator ahli. Hasil yang didapat memberi gambaran bahwa bahan ajar digital Matematika SD menggunakan whiteboard animation yang dikembangkan telah valid dan dapat digunakan dalam pembelajaran.

2. Praktikalitas bahan ajar digital Matematika SD menggunakan whiteboard animation secara keseluruhan sangat praktis. Praktikalitas perangkat pembelajaran Matematika diketahui dari hasil angket respon mahasiswa yang telah mengikuti pembelajaran dengan menggunakan bahan ajar digital Matematika SD menggunakan whiteboard animation dengan rata-rata 92,5\% dan wawancara mahasiswa yang tertarik mengajar dan belajar menggunakan 
217 Pengembangan Bahan Ajar Digital Matematika SD Menggunakan Whiteboard Animation Untuk Mahasiswa PGSD STKIP PGRI Lubuklinggau- Akmal Rijal, Azimi

DOI: https://doi.org/10.31004/basicedu.v5i1.640

bahan ajar digital Matematika SD menggunakan whiteboard animation. Hasil ini memberi gambaran bahwa penggunaan bahan ajar digital Matematika SD menggunakan whiteboard animation bagi mahasiswa sangat praktis dan dapat membantu meningkatkan minat mahasiswa dalam pembelajaran.

\section{UCAPAN TERIMA KASIH}

Penulis mengucapkan terima kasih kepada Kementerian Riset dan Teknologi/ Badan Riset dan Inovasi Nasional Republik Indonesia telah membiayai penelitian melalui program hibah Penelitian Dosen Pemula (PDP) pada tahun pelaksanaan 2020 dan terima kasih juga kepada civitas akademik STKIP PGRI Lubuklinggau khususnya dosen dan staf program studi PGSD.

\section{DAFTAR PUSTAKA}

Barry, K. (2016). The effects of using an interactive whiteboard on the academic achievement of university students. In AsiaPacific Forum on Science Learning and Teaching. In Asia-Pacific Forum on Science Learning and Teaching, 12, In Asia-Pacific Forum on Science Learning and Teac.

Desvianti $^{1}$, Desyandri ${ }^{2}$, Darmansyah ${ }^{3}$, M. R. (2020). Jurnal basicedu. Jurnal Basicedu, 1(4), 79-83.

Herawani, nellly. H. dan Y. F. (2019). Jurnal basicedu. Jurnal Basicedu, 3(2), 524-532.

Kementerian Pendidikan dan Kebudayaan. (2016). Guru Pembelajar. Direktorat Jenderal Guru dan Tenaga Kependidikan.

Kementerian riset teknologi dan pendidikan tinggi. (2018). Pengembangan Iptek dan Pendidikan Tinggi di Era Revolusi Industri 4.0. https://www.ristekdikti.go.id/siaran- pers/pengembangan-iptek-dan-pendidikantinggi-di-era-revolusi-industri-4-0/

Nieveen, N. (2007). An Introduction to Educational Design Research. Enschede. Institute for Curriculum Development (SLO).

Plomp, T. (2013). Educational Design: Introduction. From Tjeerd Plomp (eds). Educational \& Training System Design: Introduction. Design of Education and Training (in Dutch). Utrecht (the Netherlands): Lemma. Faculty of Educational Science and Technology, University of Twente.

Sugiyono. (2011). Metode Penelitian Kuantitatif Kualitatifdan $R \& D$. Alfabeta.

Suharsimi, A. (2012). Dasar-Dasar Evaluasi Pendidikan. Bumi Aksara.

Suherman, W. S., Dapan, Guntur, \& Muktiani, N. R. (2019). Development of traditional children play based instructional model to optimize development of kindergarteners' fundamental motor skill. Cakrawala Pendidikan, 38(2), 356-365. https://doi.org/10.21831/cp.v38i2.25289

Sukardi. (2011). Evaluasi Pendidikan, Prinsip dan Operasionalnya. Bumi Aksara.

Weaver, Barbara E. \& Nilson, L. B. (2005). Notebook in Class: What Are They Good For? What Can You Do With Them? New Directions in Teaching and Learning, 101, $3-13$.

Wijayanti, R., Hasan, B., \& Loganathan, R. K. (2018). Media comic math berbasis whiteboard annimation dalam pelajaran matematika. Jurnal Riset Pendidikan Matematika, 5(1), 53. https://doi.org/10.21831/jrpm.v5i1.19207 